DOI: $10.24143 / 2073-5537-2020-4-98-104$

УДК [330.44:339.18]:[338.124.4:364.22/.26]

\title{
HOW COVID-19 CHANGED DIMENSIONS OF HUMAN SUFFERING AND POVERTY ALLEVIATION: ECONOMIC ANALYSIS OF HUMANITARIAN LOGISTICS
}

\author{
Samrat Ray \\ Indian Institute of Management, \\ Ranchi, India
}

\begin{abstract}
The paper is focused on the influence of coronavirus pandemic on the global poverty and the relief operations in humanitarian logistics during the crisis. The conclusions are made about a significant paradigm shift in the organizational ecosystem caused by the pandemic. In modern conditions the work of logistics personnel and cluster management specialists have undergone many changes. The mass media play an integral role in logistics forecasting and subsequent poverty reduction initiatives. It is recommended to encourage corporate communication at the lowest level to achieve development goals in the face of growing fear of migration and job loss. There have been studied the results of practical experiments carried out in distant villages of India. The economic aspects of poverty alleviation have been analyzed using human capital method through understanding of deep philosophical morals of poverty, innovation economics, coordination of humanitarian agencies for opening innovative channels amidst rising death tolls and other critical situations. The logical deductive venue is far reaching as circumscribed by the past experiences in humanitarian deliveries and relief measures, which has propounded the novel grounds of research gaps in integration. The problem of poverty alleviation has been seriously contested and debated objectively by mapping the economic state of industries, as well as logistic operations to develop strategies that are ready for use on the ground. The question is raised whether public funding and aid can be sufficient to obtain a balance in the ecosystem of the livelihoods of the poor. Recovery phases must be structured and planned ahead of time during any pandemic, and COVID-19 should be no exception.
\end{abstract}

Key words: poverty alleviation, humanitarian logistics, crisis, COVID, pandemic.

For citation: Samrat Ray. How COVID-19 changed dimensions of human suffering and poverty alleviation: economic analysis of humanitarian logistics. Vestnik of Astrakhan State Technical University. Series: Economics. 2020;4:98-104. (In Russ.) DOI: 10.24143/2073-5537-2020-4-98-104.

\section{Introduction}

The present day situation has created a drastic change in not only economic models and way of thinking around the world but has also hindered many supply chain processes. The fear behind human disgrace cannot be measured by mere mathematical tools for recovery and stabilization phases counting towards total recovery of human sufferings [1]. There are many facets of global crisis management and various theoretical aspects which need to be studied for bringing in parity in human sufferings and innovation processes. Innovation has been long a much debated issue which has seen theoretical modifications needed desperately to sustain global supply and demand curve. The recent pandemic has fostered many innovative measures in supply chain management (SCM) as well as in human capital management (HCM) which has been a much researched venue for global business operations. It is well known that global logistics which has been widely neglected till 2004 is now being highly debated in the scientific community as well as in international business schools where new case studies like Amazon and HP have been bossing around for a few decades. Few papers have been studied in depth regarding poverty alleviation, poverty trap, logistics in relief measures and crisis management. Though the bottom-line is same regarding business logistics as well as innovation in HCM, there lies a difference in operations in conflict zones and poverty relief measures in HCM. It is worthwhile to point out that COVID has been a drastic change in institutional reforms as well as heuristic platforms in innovation cycles. Though in one part it is highly essential to supply the demand side of HCM it is highly needed in current circumstances to provide a long term sustainable goal for relief and innovation channels of growth. Proper channels of qualitative studies pertaining to HCM are still in nascent stage and it is necessary during pandemic to understand what poverty is. Why few people choose to be poor? 
What is a poverty trap? How better HCM operations can be integrated for relief measures and how poor people can be better involved in the HCM delivery process for poverty eradication and global pandemic relief. The dynamics of poverty can be better understood by playing a role factor in poverty infested regions and developing live tools understanding the myths and dilemma of poverty. Mere philosophical or economic calculations are not sufficient while deciphering the roots of the poverty disease. Is poverty a disease? [2]. Can it be termed as a trap? Do people choose to be poor? [3]. How can poverty be visualized or create a deduction for the better judgment and ethical beliefs? These are pertinent topics around which our study will go round because without understanding poverty the deductive phase cannot be reached and HCM will fall apart if we study only digitalization and rapid response measures for HCM. Human actions are the basis of any economic foundations and decision making and noteworthy is to point out that crisis like COVID has shown the rise of V-shaped curves which cannot be better aligned to human understanding and judgments. Innovation channels in health economics showed a new paradigm shift which can be fostered only if the backbone of SCM is strong enough and requires immediate integration of various players in HCM operations.

The global debate over the integration and the effectiveness of the cooperation channels between international nongovernmental players and logistics companies is the key question of today's disaster relief. The studies have been generated for understanding HCM integration with disaster frontline workers and myths behind adaptability in poverty reliefs and literacy campaigns. Previous studies in MIT Logistics center have shown the changes and disruption, which looks like a chain reaction offering whipping effects of disruption in channels [4-6]. The manufacturing hub which was highly impacted by coronavirus pandemic has brought in restrictive measures and quarantine phases stalling growth and productivity in major manufacturing hubs in China. Such measures have impacted the innovation process in multinational organizations which highly depend on supply of essential finished goods and parts for its high tech equipment. Such restriction has further impacted industry services and other modes as the countries worldwide have stopped regional traffic movements and logistics in air, sea and ocean. Inventory analysis and demand forecasting needed to be addressed at large to understand very critical aspects like consumer behavior across various sectors during pandemic. The study of Chinese industry is essential to understand dichotomy of the various logistical imperatives in smaller zones which has been at the receiving ends of relief measures. The interzonal logistic network which has been highly affected due to governmental and national closure of borders has experienced the unforeseen recession and poverty rise and a hunger index drive. There is worth pointing out that implications of the bottom of the pyramid model for poverty alleviation cannot be grossly explored as supply chains have interrupted and caused changes in supply side as well as behavioral patterns of consumer demands and preferences. It is also important to note that the pandemic has given rise to fakeness and disorder in product peripherals. Hoarding is also an important decision making factor which arises amidst rising tensions and fear factor creating imbalances in supply-demand curves.

\section{Methodology}

As for the moral philosophical judgment, the research was focused, to a greater extent, on live tools and field experiments to undermine the essences derived from poverty [7]. An extensive field work was carried out on studying crisis management, disaster reliefs and poverty eradication. There raised a special concern as COVID possessed serious healthcare deficiencies in basal metabolic rate (BMR) as well as in balanced diet and were introduced the restrictive measures in SCM operations due to Indian Government laws restricting logistical as well as human transfers due to containment from spreading a novel coronavirus. For the field experiment the extensive work was carried out by an international non-government organization in the Sunderban district in West Bengal, India. Sunderban is basically a region where people are engaged in fishing activities and there is a dense mangrove zone. Mangrove cultivation is also aided by the non-governmental organizations in local collaboration amounting to $60 \%$ of human activity in regions with tribal populations. With the population density of around 10,000 people living under poverty line the range is critical, because malnutrition amounts to $45 \%$ of population. COVID in the following months have caused the drastic human migration, and the restrictive measures by local authorities have also hindered the government relief measures and the Central bank relief funds did not lower the human suffering index. MIT Center for Logistics and Transport has shown in clarity the whip effects on the suppliers due to sliding down manufacturing as well as 
retail sales. Such evidence was clearly manifested in 2008 during the USA recession. The report over 2011 was based on empirical foundations of logistical analysis during the crisis period. This report has totally vanquished the comparison of the COVID pandemic with other earlier historical events of MERS/SARS, Ebola pandemics.

For control in the field experiment, an international non-governmental organization was chosen randomly after the proper analysis of its operational background and case modulations.

1. Case Study: International Kolkata Heritage Society: The organization works in rural areas of West Bengal in India in collaboration with local bodies and governmental organizations bringing in relief and assistance during and after the crisis in rural districts. The NGO is self-funded with occasional assistance from member-institutions and other allied forces which contribute sustainably towards its mission and vision. The organization has worked extensively in migration study, poverty alleviation and agricultural economics for the benefit of human lives in danger.

Questionnaires and interviews were conducted among the regional tribal population and other respondents in the Sunderban district in West Bengal, India. The pandemic has resulted in disruptions in cluster organization and has forced the closure of primary income sources like fishery and agriculture in the region. Sunderban is a mangrove region where $80 \%$ of the population is highly involved in fishing and other activities. With collaboration from Government of West Bengal, the nongovernmental organization has helped in local farming of mangrove with export potentials. COVID crisis has brought in drastic changes in the modes of farming and procurement of essential agricultural products and fertilizers. The cross reference of MIT reports which clearly states the essential disruption of supply-demand chains has been clearly portrayed in these zones with illiterate and digitally weak population. Such zones are not complacent to fighting vast scale pandemics in hand, they require extensive policy changes and innovations in logistics and SCM operations [8]. According to the reports and analysis of the data obtained, the tribal population is not armed for fostering future transition and recovery positions amidst rising death tolls and causalities arising out of pandemic crisis. COVID has indeed brought in changes in lifestyle and requires gross measures of future forecasting and resilient actions and goals. Logistics has been an important part in the region with over 10,000 fisher men dislodged from their occupation. Providing relief measures to farmers is also important tool mark as the initial relief forces have been disrupted due to already existent natural disaster as well as cyclones, which crushed the economy of the region. The recent disruption of the railway system, which has been a major transportation venue for agricultural farmers and retailers, has created huge monetary losses to the informal sector where nearly 35 lakh people are carried every day by the local trains across various villages in West Bengal. Government data have altogether minimized the future prospects of retailing as COVID has forced a vast range of disruptive measures.

2. Jute Industry in India: Another important analysis is about the state of affairs in the jute industry and its logistics where a sizeable poor population is employed in the annual production of jute. It is important to note that West Bengal is an important jute producing region where different finished products of jute are manufactured in the small and medium-size enterprises where a lot of people are employed in printing, designing and creating strategy for offshore handling of jute products (Tables 1,2).

Table 1

Productivity analysis of Jute Spinning in West Bengal [9]

\begin{tabular}{|c|c|c|c|c|c|c|c|c|}
\hline \multirow{2}{*}{ Month } & \multirow{2}{*}{$\begin{array}{c}\text { Frame } \\
\text { runes/day } \\
\text { (Avg) }\end{array}$} & \multicolumn{2}{|c|}{$\begin{array}{l}\text { Production } \\
\text { in MT }\end{array}$} & \multirow{2}{*}{$\begin{array}{l}\text { Actual production/ } \\
\text { frame/ day in kgs }\end{array}$} & \multirow{2}{*}{ No. of winder } & \multirow{2}{*}{$\begin{array}{c}\text { Production/ } \\
\text { winder in kgs }\end{array}$} & \multicolumn{2}{|c|}{ Efficiency, \% } \\
\hline & & Target & Actual & & & & Target & Actual \\
\hline November 2019 & 168 & 52.6 & 42.6 & 254 & 154 & 277 & 80 & 64.8 \\
\hline December 2019 & 170.5 & 48.8 & 39.7 & 233 & 166 & 240 & 80 & 64.8 \\
\hline January 2020 & 150.5 & 42.5 & 34.01 & 226 & 143 & 238 & 80 & 63.9 \\
\hline February 2020 & 163 & 46.0 & 36.64 & 225 & 148 & 248 & 80 & 63.7 \\
\hline March 2020 & 76.2 & 22.4 & 19.7 & 259 & 105 & 188 & 80 & 70.3 \\
\hline April 2020 & 0 & 0 & 0 & 0 & 0 & 0 & 0 & 0 \\
\hline May 2020 & 98 & 29.8 & 23.9 & 244 & 95 & 252 & 80 & 64.3 \\
\hline June 2020 & 155 & 47.7 & 40.65 & 261 & 150 & 271 & 80 & 67.9 \\
\hline
\end{tabular}


Productivity and Resilience in jute production in West Bengal [10]

\begin{tabular}{|l|c|c|}
\hline \multicolumn{1}{|c|}{ Months } & Production on kgs & Delivery in Kgs \\
\hline December 2019 & 53163.00 & 47000.00 \\
\hline January 2020 & 39306.00 & 49902.00 \\
\hline February 2020 & 64947.00 & 60000.00 \\
\hline March 2020 & 46264.00 & 36000.00 \\
\hline April 2020 & 0 & 0 \\
\hline May 2020 & 245628.00 & 203970.00 \\
\hline June 2020 & 181505.00 & 204011.00 \\
\hline Total & 630813 & 600883.00 \\
\hline
\end{tabular}

The above charts fully comply with the changes in demand and production figures which kept swinging as noted from the above tables showing consumption and wastages in jute spinning. Jute industry is an important economic indicator in a few regions in India. The government took special measures to ensure continuity in livelihood in the region by relaxing the restrictive measures due to COVID and creating subsidy and extending credits to jute mill workers. The industry is promising in India with a big export potential and employment opportunities.

\section{Deduction}

It is well known that COVID has posed the new challenges and dynamical prospective in humanitarian operations and developmental goals of not only governments worldwide but also international integration and cooperation among various sectors and peripheral activities. The entire gamut of organizational operations has shifted during the peak phases and reclining curves of the pandemic. It was also necessary for understanding poverty in depth, poverty traps as well as valuation of money and monetary supply during crisis. We also understood nuances arising of conflict on the bottom of the pyramid model where vertical integration of the lowest strata into economic activity was highly encouraged but due to crisis the migration tendency, psychological imperatives arising from human action and fear factor have degenerated the causal effects of the model in general. A more philosophical and deductive approach was envisioned for the purpose of generating a blueprint for HCM operations in crisis. There are indeed the policy imperatives which are deducted after a careful analysis at the grassroots level. Such policies can be taken as a yardstick for the future implications by academicians for the research and development in humanitarian logistics.

1. Mapping of supply of fertilizers is important as during disruption phases it is necessary to cognitively analyze the future trends and practices.

2. If fertilizers and equipment are disrupted, this will affect the manufacturing turn around and this will be detrimental for the receiving ends in agricultural hotspots. So particular government intervention and policy should be analyzed and implemented to charter the sustainable phases of risk mitigation in agricultural deliveries which may not affect the harvesting phases. As for the late season, there remains a high chance of disruption in annual harvesting which may in turn be a severe case for poor farmers who rely mainly on agriculture in India; it is imperative for government to offer subsidy and direct cash endowments which may substitute their losses.

3. The product transfer and product integration for mapping the suppliers is necessary.

4. Customer and product connectivity is to be mapped as disruption may cause the inventory losses which may in turn create financial burden and huge pertinent losses.

5. Supplier surgery is important for the companies to understand the notion behind supply and inexpensive transportation of goods.

6. Further mapping requires to understand deliverability as well as quality of product line.

\section{Conclusion}

There has been indeed the paradigm shift in operational and organizational ecosystem arising out of the COVID pandemic and financial misbalance. The result of the research has pointed towards wide ranging policy implications for the future reference and best practices in logistics operations and engineering systems in HCM. The case study analysis and filed work conducted have brought in novel changes in operations of logistics personnel and cluster management professionals. The new idea 
of creating clusters in logistics operations and peripheral HCM infrastructure across the boundaries have helped in risk mitigation and understanding the urgency of necessity community deliverables and goods transportation. The well-organized transportation mechanism and engineering operations in the big cities during crisis differ in handling resources in scarce endowment zones where illiteracy and poverty are often a determining factor. There is always a deep concern of the effects which are generated in the supply side in the bottom of the pyramid which can definitely hinder all sectors of operations irrespective of social and economic strata. Further it should be noted that media play an integral part in logistical prediction and subsequent initiatives in poverty reduction. Fake news and its indignation can cause widespread panic and this must be curbed by the local as well as governmental bodies in the interest of public. Corporate communications on the ground level must be encouraged to foster developmental goals amidst rising fears of migration and job losses. There lies the challenge of creating balance in logistical movements as global shutdown has made impossible on the bottom line of the economic pyramid with widespread losses in financial incomes and livelihood of poor people. The real question is still whether government funding and aid can be enough for eradicating or creating a balance in ecosystem of livelihood of the poor? What really will happen to the bottom of the pyramid trapped in poverty? What will be the behavioral changes in human actions during the pandemic? It is also important to note that recovery phases need to be structured and preplanned for during any pandemic, and COVID is no exception to it.

\section{REFERENCES}

1. Alexander D. Globalization of disaster: Trends, problems and dilemmas. 2006. Available at: https://www.questia.com/library/journal/1G1-146073416/globalization-of-disaster-trends-problems-and-dilemmas (accessed: 02.11.2020).

2. Stiglitz J. Humanitarian Logistics. Journal of International Affairs, 2009, vol. 59, no. 2, pp. 1-22.

3. Samrat Ray, Dossou Yedehou Leandre. Impact of Innovation on Economic Growth: A Comparative Analysis of the Economic Community of West African States and India. International Research Journal, 2020, no. 6 (96), part 4, pp. 53-56.

4. Why Logistics is Central to Disaster Management. Available at: http://www.logistik.tuberlin.de/fileadmin/fg2/Forschung/Projekte/2010-10-27_Vortrag_Kessler_Schwarz.pdf (accessed: 01.08.2020).

5. Kovács G., Spens K. M. Humanitarian logistics in disaster relief operations. International Journal of Physical Distribution \& Logistics Management, 2007, vol. 37, no. 2, pp. 99-114.

6. Humanitarian Logistics: Empirical Evidences from a Natural Disaster. Available at: https://www.sciencedirect.com/science/article/pii/S1877705814010327 (accessed: 05.09.2020).

7. Cozzolino A., Rossi S., Conforti A. Agile and lean principles in the humanitarian supply chain: The case of the United Nations World Food Programme. Journal of Humanitarian Logistics and Supply Chain Management, 2012, vol. 2, no. 1, pp. 16-33.

8. State of Supply Chain Sustainability Report 2020. Available at: https://ctl.mit.edu/pub/report/statesupply-chain-sustainability-report-2020 (accessed: 14.06.2020).

9. Effect of COVID-19 Pandemic on the Market Price of Jute in India. Available at: https://www.agriculturejournal.org/volume8number2/effect-of-covid-19-pandemic-on-the-market-price-of-jutein-india/ (accessed: 13.07.2020).

10. Bi-weekly Lockdown in West Bengal is Likely to Affect Its Jute Industry. Available at: https://textilevaluechain.in/2020/07/24/bi-weekly-lockdown-in-west-bengal-is-likely-to-affect-its-jute-industry/ (accessed: 01.06.2020).

The article submitted to the editors 08.11.2020

\section{INFORMATION ABOUT THE AUTHOR}

Samrat Ray - India, 700033, Ranchi; Indian Institute of Management; Senior Researcher of the Department of Economics; samratray@rocketmail.com. 


\title{
ВЛИЯНИЕ КОРОНАВИРУСНОЙ ИНФЕКЦИИ (COVID-19) НА РОСТ ЧЕЛОВЕЧЕСКИХ ЛИШЕНИЙ \\ И БОРЬБУ С БЕДНОСТЬЮ: ЭКОНОМИЧЕСКИЙ АНАЛИЗ ГУМАНИТАРНОЙ ЛОГИСТИКИ
}

\author{
Самрат Рэй \\ Индийский институт менеджмента, \\ Ранчи, Индия
}

\begin{abstract}
Рассматриваются проблемы сокращения доходов населения планеты и анализируются эффективные мероприятия гуманитарной логистики для борьбы с бедностью во время пандемии, вызванной коронавирусной инфекцией (COVID-19). Сделаны выводы о значительном сдвиге парадигмы в организационной экосистеме, вызванном пандемией. В современных условиях произошли глобальные изменения в работе логистического персонала и специалистов по управлению кластером. Неотъемлемую роль в логистическом прогнозировании и последующих инициативах по сокращению бедности играют средства массовой информации. Рекомендовано поощрять корпоративную коммуникацию на нижнем уровне для достижения целей развития в условиях растущего страха перед миграцией и потерей рабочих мест. Проведено исследование результатов экспериментов в отдаленных деревнях Индии. Проанализированы экономические аспекты борьбы с бедностью при использовании метода управления человеческим капиталом, глубокого понимания нравственных проблем бедности, инновационной экономики, координации гуманитарных мероприятий для открытия инновационных логистических каналов, понимания человеческих лишений на фоне роста числа жертв COVID-19 и других кризисных ситуаций. Логическая дедуктивная площадка перспективна для изучения богатого опыта оказания гуманитарной помощи, а также для исследования основания пирамиды. Вопрос обнищания населения обсуждается и объективно решается путем картирования экономического состояния отраслей, а также логистических операций по разработке стратегий, готовых к применению. Поставлен вопрос: сможет ли государственное финансирование оказать достаточную помощь бедствующим для создания баланса в экосистеме средств. Фазы восстановления должны быть структурированы и заранее спланированы во время любой пандемии, COVID-19 не должен являться исключением.
\end{abstract}

Ключевые слова: борьба с бедностью, гуманитарная логистика, кризис, коронавирусная инфекция (COVID-19), пандемия.

Для цитирования: Caмрат Рэй. Влияние коронавирусной инфекции (COVID-19) на рост человеческих лишений и борьбу с бедностью: экономический анализ гуманитарной логистики // Вестник Астраханского государственного технического университета. Серия: Экономика. 2020. № 4. C. 98-104. DOI: 10.24143/2073-5537-2020-4-98-104.

\section{СПИСОК ЛИТЕРАТУРЫ}

1. Alexander D. Globalization of disaster: Trends, problems and dilemmas. 2006. URL: https:/www.questia.com/library/journal/1G1-146073416/globalization-of-disaster-trends-problems-and-dilemmas (дата обращения: 02.11.2020).

2. Stiglitz J. Humanitarian Logistics // Journal of International Affairs. 2009. Vol. 59. N. 2. P. 1-22.

3. Samrat Ray, Dossou Yedehou Leandre. Impact of Innovation on Economic Growth: A Comparative Analysis of the Economic Community of West African States and India // International Research Journal. 2020. N. 6 (96). Part 4. P. 53-56.

4. Why Logistics is Central to Disaster Management. URL: http://www.logistik.tuberlin.de/fileadmin/fg2/Forschung/Projekte/2010-10-27_Vortrag_Kessler_Schwarz.pdf (дата обращения: 01.08.2020).

5. Kovács G., Spens K. M. Humanitarian logistics in disaster relief operations // International Journal of Physical Distribution \& Logistics Management. 2007. Vol. 37. N. 2. P. 99-114.

6. Humanitarian Logistics: Empirical Evidences from a Natural Disaster. URL: https://www.sciencedirect.com/science/article/pii/S1877705814010327 (дата обращения: 05.09.2020).

7. Cozzolino A., Rossi S., Conforti A. Agile and lean principles in the humanitarian supply chain: The case of the United Nations World Food Programme // Journal of Humanitarian Logistics and Supply Chain Management. 2012. Vol. 2. N. 1. P. 16-33. 
8. State of Supply Chain Sustainability Report 2020. URL: https://ctl.mit.edu/pub/report/state-supplychain-sustainability-report-2020 (дата обращения: 14.06.2020).

9. Effect of COVID-19 Pandemic on the Market Price of Jute in India. URL: https://www.agriculturejournal.org/volume8number2/effect-of-covid-19-pandemic-on-the-market-price-of-jutein-india/ (дата обращения: 13.07.2020).

10. Bi-weekly Lockdown in West Bengal is Likely to Affect Its Jute Industry. URL: https://textilevaluechain.in/2020/07/24/bi-weekly-lockdown-in-west-bengal-is-likely-to-affect-its-jute-industry/ (дата обращения: 01.06.2020).

Статья поступила в редакцию 08.11.2020

\section{ИНФОРМАЦИЯ ОБ АВТОРЕ}

Cамрат Рэй - Индия, 700033, Ранчи; Индийский институт менеджмента; старший научный сотрудник кафедры экономики; samratray@rocketmail.com. 